\title{
Endoscopic Endonasal Transsphenoidal Treatment for Acromegaly: 2010 Consensus Criteria for Remission and Predictors of Outcomes
}

\author{
Akromegalinin Endoskopik Endonazal Transsfenoidal Tedavisi: 2010 \\ Kriterlerine Göre Remisyon Oranları ve Remisyonu Etkileyen Faktörler
}

Ali Erdem YILDIRIM ${ }^{1}$, Mert SAHINOGLU ${ }^{1}$, Denizhan DIVANLIOGLU ${ }^{1}$, Fatih ALAGOZ ${ }^{1}$, Ahmet Gurhan GURCAY ${ }^{2}$, Ergun DAGLIOGLU ${ }^{1}$, Hilmi Onder OKAY ${ }^{3}$, Ahmed Deniz BELEN ${ }^{1}$

${ }^{1}$ Ankara Numune Research and Education Hospital, Department of Neurosurgery, Ankara, Turkey

${ }^{2}$ Ankara Ataturk Research and Education Hospital, Department of Neurosurgery, Ankara, Turkey

${ }^{3}$ Erzurum Research and Education Hospital, Department of Neurosurgery, Erzurum, Turkey

Corresponding Author: Ali Erdem YILDIRIM / E-mail: alierdemyildirim@gmail.com

\begin{abstract}
AIM: Acromegaly is a chronic disorder characterized by enhanced growth hormone (GH) secretion and elevated insulin-like growth factor-I (IGF-I) levels, usually caused by pituitary adenomas. In this retrospective study, we reviewed our experience with endoscopic endonasal transsphenoidal surgery (EETS) with in remission rates using the 2010 consensus criteria, predictors of remission and associated complications.

MATERIAL and METHODS: The authors retrospectively analyzed data from 56 acromegalic patients who underwent pure EETS. Tumors were classified according to size and suprasellar/parasellar extension. The criteria of remission were GH levels $<1 \mathrm{ng} / \mathrm{mL}$ randomly, $<0.4 \mathrm{ng} / \mathrm{mL}$ after oral glucose tolerance test and normal IGF-I levels for age and sex within the first 3 and 6 months after surgery.

RESULTS: Biochemical remission was achieved in 4 of 5 microadenomas (80\%) and in 33 of 51 macroadenomas (64.7\%). The total remission rate was $66.1 \%$ (37 of 56 adenomas). Age, gender and suprasellar extension did not affect the remission rate. However, cavernous sinus invasion, sphenoid sinus invasion and history of prior surgery were associated with lower rates of disease control.

CONCLUSION: EETS represents an effective and safe option for the treatment of patients with acromegaly. High disease control rates and a small number of complications are some of the most important points related to the technique.
\end{abstract}

KEYWORDS: Acromegaly, Endoscopic transsphenoidal surgery, Remission, Predictive factors

öz

AMAÇ: Akromegali genellikle hipofiz adenomuna bağlı gelişen büyüme hormonu (GH) aşırı salınımı ve yükselmiş insülin benzeri büyüme faktörü-1 (IGF-I) ile karakterize kronik bir hastalıktır. Bu retrospektif çalışmada, 2010 remisyon kriterleri kullanılarak endoskopik endonazal transsfenoidal cerrahi (EETC) ile tedavi edilen akromegali hastalarında remisyon oranı, remisyonu etkileyen faktörler ve ilgili komplikasyonlar sunuldu.

YÖNTEM ve GEREÇLER: Pür EETC ile tedavi edilmiş $56 \mathrm{GH}$ salgılayan hipofiz adenomu tanılı hastalar retrospektif olarak incelendi. Adenomlar boyutlarına göre mikro/makroadenom olarak ve suprasellar/parasellar yönelimlerine göre sınıflandırıldı. Hastalığın remisyon kriterleri olarak, rastgele bakılan $\mathrm{GH}$ düzeyi $<1 \mathrm{ng} / \mathrm{mL}$, oral glukoz tolerans testi sonrası $\mathrm{GH}$ düzeyi $<0,4 \mathrm{ng} / \mathrm{mL}$ ve cerrahi sonrası ilk 3-6 ay arasında bakılan IGF-I düzeyinin yaşa ve cinsiyete gore normal olması kabul edildi.

BULGULAR: 5 mikroadenomun 4'ünde (\%80), 51 makroadenomun $33(\% 64,7)$ ünde remisyon sağlandı. Hastaların tümü incelendiğinde, remisyon oranı 56 hastada $37(\% 66,1)$ olarak bulundu. Yaşın, cinsiyetin ve suprasellar büyümenin remisyon oranlarına etkisinin olmadığı görüldü. Ancak daha önce cerrahi geçirmiş olmak, kavernöz sinüs ve sfenoid sinüs invazyonunun remisyon oranlarını azalttığı saptandı.

SONUÇ: EETC, akromegalinin tedavisinde etkili ve güvenli bir yöntemdir. Bu teknikle yüksek başarı ve düşük komplikasyon oranlarına ulaşmak mümkündür.

ANAHTAR SÖZCÜKLER: Akromegali, Endoskopik transsfenoidal cerrahi, Remisyon, Etkili faktörler 


\section{INTRODUCTION}

Acromegaly is a chronic disease characterized by high levels of growth hormone $(\mathrm{GH})$ and insulin-like growth factor-I (IGF-I) primarily dependent upon a pituitary adenoma (24). Acromegaly is usually manifested by progressive bone and cartilage growth that leads to dysmorphic craniofacial features and extremity changes, as well as cardiovascular, metabolic, and respiratory complications. Elevated $\mathrm{GH}$ and IGF-I levels may cause various systemic complications such as hypertension, cardiomyopathy, diabetes, sleep apnea, and arthritis (8). Untreated acromegaly and high levels of $\mathrm{GH} /$ IGF-I are associated with increased mortality as observed in patients with $32 \%$ increased risk for all-cause mortality (26). Cardiovascular disease, respiratory complications and cancers are the main factors related to poor outcome in these patients $(5,12)$. Therefore, acromegalic patients have a significant reduction in their quality of life, but the standardized mortality ratio returns to that of the normal population if GH levels are normalized (8). According to 2010 consensus guidelines, remission is defined as a normal IGF-I level and random $\mathrm{GH}$ level less than $1.0 \mathrm{ng} / \mathrm{mL}$ or $\mathrm{GH}$ level less than 0.4 $\mathrm{ng} / \mathrm{mL}$ during an oral glucose tolerance test (11).

It stands to reason that an effective treatment of acromegaly is necessary. Treatment options for acromegaly include surgery, medical therapy, and radiotherapy. Surgery is the first choice of treatment for $\mathrm{GH}$-secreting adenomas due to rapid control of GH/IGF-I levels and lower costs $(13,14)$. Conventionally, transsphenoidal microsurgery has been considered the best surgical approach for most pituitary adenomas such as GH secreting adenomas $(12,13,30)$. Nowadays, the endoscopic transsphenoidal approach has become an initial option for resection of all pituitary adenomas because of having a lot of advantages such as better illumination, improved visualization, less nasal trauma, increased patient comfort, using angle scopes to reach the parasellar region, and achieving better results on tumor removal $(4,13,30)$. In published literatures, biochemical remission rates following surgical intervention for acromegaly range from 34 to $83 \%(12,17,18,23,27,30,37)$. Most of these studies show that, microadenomas tend to be more responsive to surgical treatment than macroadenomas, although tumor size has not been consistently reported to be predictor of biochemical remission. The factors reported to be associated with increased likelihood of biochemical remission include lower Knosp score, preoperative GH level, and preoperative IGF-1 level (17). But, there is limited published literature with new criteria for acromegaly on outcomes and factors affecting the remission rates. Patients for which biochemical remission is not achieved with initial resection are left with few options; reoperation, medical therapy and radiosurgery $(32,36)$. Medical management and radiosurgery are costly and variably effective options.

In this study we describe our experience with pure endoscopic endonasal transsphenoidal approach in 56 patients with $\mathrm{GH}$ secreting pituitary adenomas. Our aim was to analyze the predictors of biochemical remission rates of $\mathrm{GH}$-secreting pituitary adenomas after endoscopic resection by using the more stringent 2010 consensus guidelines to assess disease remission in acromegaly.

\section{PATIENTS and METHODS}

\section{Patient Demographics}

Data were collected by retrospective review of medical records of all patients treated by EETS at Ankara Numune Education and Research Hospital, Department of Neurosurgery, Ankara, Turkey, between June 2009 and September 2013. Among the 60 acromegalic patients operated by EETS within this time period, 4 patients who did not have adequate GH and IGF-I data and therefore could not be evaluated for remission were excluded from the analysis. Fifty-six patients with sufficient data with regard to postoperative GH and IGF-I values, which were assessed more than 6 months postoperatively for evaluation of remission, were included in this study.

Of the 56 patients who were included in this retrospective study, 39 were female and 17 were male, and the mean age was 42.3 years (range, 23-65). Sixteen patients had recurrent or relapsing adenomas, 14 of them had previously been operated in other clinics.

The mean follow-up was 18 months.

\section{Radiological Analysis}

The size and the extension of the tumor as well as the degree of resection were assessed by pre- and post-operative T1 or T2-weighted magnetic resonance (MR) images of patients. Postoperative imaging was performed 3 and 6 months after surgery. Tumor sizes were classified as microadenomas $(<1 \mathrm{~cm}$ in greatest diameter) or macroadenomas $(\geq 1 \mathrm{~cm}$ in greatest diameter) on coronal images.

The suprasellar extension of the tumors was classified according to Modified Hardy's classification (35). Grade 0 means that the tumor remains intrasellar. Grade A means that the tumor is expanding into the suprasellar cistern. Grade $B$ means that the anterior recess of the third ventricle is obliterated. Grade C means that the floor of third ventricle is grossly displaced.

The suprasellar extension and sphenoid sinus invasion by the tumors were classified according to Hardy-Wilson classification (Hardy classification, modified by Wilson) (35) (Table I). The degree of suprasellar and parasellar extension was graded as Stages $A-E$, and the degree of sellar floor erosion as Grades I-IV.

Cavernous sinus invasion by the tumors was classified according to Knosp classification. Knosp classification is based upon parasellar extension of the tumor in the coronal section of MRI scans with internal carotid artery (ICA) serving as the radiological landmark (19). It consists of five grades. Grade 0 means that the adenoma does not encroach into the cavernous sinus space or cross the medial aspect of intra- and supra-cavernous ICA. Grade I means that the tumor crossed the medial tangent but does not extend beyond 
Table I: Hardy Classification Modified by Wilson (Hardy-Wilson)

\begin{tabular}{|l|l|}
\hline $\begin{array}{l}\text { Stage } \\
\text { 0: no suprasellar extension }\end{array}$ & I: sella normal; tumor $<10 \mathrm{~mm}$ \\
\hline $\begin{array}{l}\text { A: extension to suprasellar } \\
\text { cistern }\end{array}$ & $\begin{array}{l}\text { II: sella enlarged; tumor } \geq 10 \\
\mathrm{~mm}\end{array}$ \\
\hline $\begin{array}{l}\text { B: recesses of third ventricle } \\
\text { obliterated }\end{array}$ & $\begin{array}{l}\text { III: local perforation of sellar } \\
\text { floor }\end{array}$ \\
\hline $\begin{array}{l}\text { C: third ventricle grossly } \\
\text { displaced }\end{array}$ & $\begin{array}{l}\text { IV: diffuse sellar floor } \\
\text { destruction }\end{array}$ \\
\hline $\begin{array}{l}\text { D: intracranial } \\
\text { E: into/beneath cavernous } \\
\text { sinus }\end{array}$ & \\
\hline
\end{tabular}

the intercarotid line. Grade II means that the tumor crossed beyond the intercarotid line but does not cross beyond the lateral tangent of intra- and supra-cavernous ICA. Grade III means that the tumor has crossed beyond the lateral tangent of intra- and supra-cavernous ICA. Grade IV means that there was total encasement of the intra-cavernous ICA by the tumor.

\section{Endocrine Analysis}

Serum GH levels were measured by immunoradiometric assay (IRMA) using commercially available kits (hGH-IRMA CT; RADIM, Roma, Italy). The sensitivity of the assay was 0.04 $\mathrm{ng} / \mathrm{ml}$. The calibrator was calibrated against the WHO 80/505 International Standard preparation ( $1 \mathrm{ng} \mathrm{hGH}=2 \mu \mathrm{IU})$. The reference ranges of $\mathrm{GH}$ were $0-16 \mathrm{ng} / \mathrm{ml}$ for women and 0-8 $\mathrm{ng} / \mathrm{ml}$ for men. Serum IGF-I was measured by a solidphase, enzyme-labeled chemiluminescent immunometric assay (Immulite IGF-I, Siemens Medical Solutions Diagnostics, UK), using the IMMULITE 1000 System. In our laboratory, the reference ranges of IGF-I in patients aged 21-25, 26-30, $31-35,36-50,51-60,61-70$, and $>70$ years were $116-358$, $117-329,115-307,94-284,81-238,69-212$, and 55-188 ng/ $\mathrm{ml}$, respectively. The analytical sensitivity of the assay was $20 \mathrm{ng} / \mathrm{ml}$. Calibration was up to $1600 \mathrm{ng} / \mathrm{ml}$ (WHO NIBSC 1 st IRR $87 / 518$ ). The within-run coefficients of variation were $3.1,4.3$ and $3.5 \%$ for the low, medium, and high points of the standard curve, respectively. The total coefficients of variation were $6.1,6.9$, and $5.8 \%$ for the low, medium, and high points of the standard curve, respectively.

Patients underwent preoperative endocrinological evaluation for fasting GH and IGF-I levels, and anterior pituitary function. Also, OGTT was performed in all patients preoperatively.

At 1-day, 1-month, 3-month, and 6-month after the operation, fasting plasma GH and IGF-I levels and anterior pituitary hormones were measured. Afterward, GH and IGFI levels were reanalyzed at every 6 months. Hormone replacement therapy was administered, if necessary, to patients with clinical and laboratory evidence of hypopituitarism. At 3 months and 6 months postoperative follow-up, patients were analyzed using remission criteria according to the following 2010 consensus guidelines (34): an IGF-I value within normal range for age and gender and a $\mathrm{GH}$ value $<0.4 \mathrm{ng} / \mathrm{mL}$ after glucose load or a random $\mathrm{GH}$ value $<1.0 \mathrm{ng} / \mathrm{mL}$. Also, patients were defined as being remission when they met surgical criteria: no residual tumor was visualized and total removal of the tumor was confirmed by MRI studies on the 1st postoperative day, and at 3-months and 6-months follow-up.

\section{Surgical Technique}

All patients were operated using the pure endoscopic endonasal transsphenoidal approach. For larger adenomas, a binostril and extended approach was preferred. Macroadenomas growing to the parasellar area were operated by using angled scopes $\left(30^{\circ}\right.$ and $\left.45^{\circ}\right)$ for gross total excision. After the removal of the tumor, multilayer skull base reconstruction by using autologous grafts and fibrin sealant was done, if necessary.

\section{Statistical Analysis}

Data were analyzed using commercially available software (SPSS version 18). Univariate comparison of continuous variables with a normal distribution was assessed using 2-sample $t$ tests, and continuous variables not meeting the normality assumption were assessed using the MannWhitney $U$ test. All categorical data were assessed by $v 2$ test or Fisher exact test, as appropriate. Remission rates were compared between degrees of invasiveness, tumor size, tumor growth direction, sex, age and preoperative hormone level. When $p$ values were $\leq 0.05$, the differences were considered statistically significant.

\section{RESULTS}

Between June 2009 and September 2013, 415 patients underwent endoscopic transsphenoidal surgery for the treatment of skull base lesions at Ankara Numune Education and Research Hospital, Department of Neurosurgery, Ankara, Turkey. Pituitary adenomas were the most common lesions treated, representing 335 of the 415 cases. In the group of functioning pituitary adenomas, the most common subtype was $\mathrm{GH}$-secreting adenomas.

During the study period, $60 \mathrm{GH}$-secreting pituitary adenomas were treated by pure EETS by the senior author (A.E.Y.). Fiftysix patients, who had sufficient data regarding postoperative GH and IGF-I values, which were assessed more than 6 months postoperatively and used for evaluation of remission, were included in this study. Seventeen of the patients were male and 39 were female. The mean age of the 56 patients was 42.3 years (range from 23 to 65 years).

All pituitary adenomas were anatomically analyzed based on MR imaging findings. Five patients had microadenomas (8.9\%) and 51 patients had macroadenomas (91.1\%). Hormonal remission was achieved by surgical treatment in 4 out of 5 microadenomas (80\%), 33 out of 51 macroadenomas (64.7\%), and totally 37 out of 56 adenomas (66.1\%). Out of 19 patients (33.9\%) that could not be cured by surgery alone, 2 had total resection and 17 patients did not. Hormonal control 
was achieved in 16 of 19 patients with medical treatment. Radiosurgery was performed in 3 patients.

In adenomas, that were classified according to Modified Hardy's classification, which is based upon only suprasellar extension of the tumor, no significant difference in remission ratios was observed between the grades ( $p>0.05$ ) (Table II).

The suprasellar/parasellar extension and sphenoid sinus invasion of the tumors were classified according to HardyWilson classification. Although the stage values, showing suprasellar extension, have no effect on the remission rates, the success rate of surgery reduced by a statistically significant level in Stage E which indicates cavernous sinus invasion and in grade 3 and 4 which show sphenoid sinus invasion ( $p \leq$ 0.05) (Table III).

However in the Knosp classification, which is based on cavernous sinus invasion, remission rates decrease significantly while invasion levels, i.e. grade, increase $(p \leq 0.05)$ (Table IV).

In our series, 16 patients underwent repeat operation for acromegaly utilizing EETS when biochemical remission was not achieved after the first operation and medical therapy. Fourteen of them underwent initial operation by different surgeons, 10 patients were operated via microscopic or endoscopic transsphenoidal approach and 4 patients were operated transcranially. Only 2 patients were operated our department via EETS by senior author. All of these 16 patients were reoperated via a pure EETS, hormonal remission was achieved in 7 of them (43.7\%), and medical therapy was stopped.

According to our study, age, sex and preoperative hormon levels did not affect the remission rates ( $p>0.05)$.

\section{COMPLICATIONS}

Postoperatively, there were 4 patients with other hormone deficits. Three patients developed panhypopituitarism, 1 patient developed hypothyroidism and adrenal insufficiency. One patient developed permanent diabetes insipidus (DI) and 2 patients developed transient DI. Transient cranial nerve (CN) III palsy developed in 1 patient. There were 2 patients (3.8\%) with CSF leaks and reoperation was done. One patient was reoperated because of hemorrhage into the sella after surgery.

\section{DISCUSSION}

Surgery is the first choice of treatment for acromegaly. The main aim in the treatment of acromegaly is the total resection of the tumor if possible, prevention of its recurrence and to restore the normal GH/ IGF-1 levels with the long-term aim of avoiding increased morbidity and mortality associated with uncontrolled serum GH and IGF-1 levels $(22,26,28,34)$.

Transsphenoidal surgery for treatment of acromegaly has been used since the initial work of Cushing (6). The development and the popularization of endoscopic transsphenoidal pituitary surgery have been associated with better tumor
Table II: Distribution of Patients According to the Modified Hardy Classification

\begin{tabular}{|c|c|c|c|}
$\begin{array}{c}\text { Modified } \\
\text { Hardy }\end{array}$ & $\begin{array}{c}\text { Number of } \\
\text { Patients }\end{array}$ & Cure & Non Cure \\
\hline 0 & 13 & 11 & 2 \\
A & 31 & 18 & 13 \\
\hline B & 6 & 3 & 3 \\
C & 6 & 5 & 1 \\
\hline
\end{tabular}

Grade 0 and A Were Compared with Grade B and C According to T Test Analysis: $p>0.05$ ).

Table III: Distribution of patients according to the Hardy Wilson Classification

\begin{tabular}{|c|r|r|r|}
\hline Hardy-Wilson & $\begin{array}{c}\text { Number of } \\
\text { Patients }\end{array}$ & Cure & Non Cure \\
\hline Stage & & & \\
\hline A & 5 & 3 & 2 \\
\hline B & 30 & 25 & 5 \\
\hline C & 5 & 3 & 2 \\
\hline D & 4 & 3 & 1 \\
\hline E & 2 & 2 & 0 \\
\hline Grade & 10 & 1 & 9 \\
\hline 1 & 5 & 4 & 1 \\
\hline 2 & 26 & 24 & 2 \\
\hline 3 & 19 & 9 & 10 \\
\hline 4 & 6 & 0 & 6 \\
\hline
\end{tabular}

Stage $0, A$ and $B$ were compared with Stage $C, D$ and $E$ according to $t$ test analysis: $p \leq 0.05$.

Grade 1 and 2 were compared with grade 3 and 4 according to $t$ test analysis: $p \leq 0.05$.

Table IV: Distribution of Patients According to the Knosp Classification

\begin{tabular}{|c|c|c|c|}
\hline Knosp & $\begin{array}{c}\text { Number of } \\
\text { Patients }\end{array}$ & Cure & Non Cure \\
\hline 0 & 7 & 7 & 0 \\
\hline 1 & 15 & 13 & 2 \\
\hline 2 & 16 & 14 & 2 \\
\hline 4 & 7 & 2 & 5 \\
\hline
\end{tabular}

Grade 0,1 and 2 were compared with grade 3 and 4 according to $t$ test analysis: $p \leq 0.05$.

resection results, which are often related to better visualization and improvement in the resection of suprasellar and parasellar components of the adenoma $(9,14)$. The success of endoscopic transsphenoidal surgery in the treatment of acromegaly has been reported by different authors $(12,17$, 
$33,15)$. In this study, we present hormonal remission results, outcomes, and predictive factors of endocrinological remission in acromagalic patients after pure endoscopic transsphenoidal pituitary surgery.

The definition of biochemical remission of acromegaly has changed noticeably over the past 2 decades. In the 1980s, postoperative $\mathrm{GH}$ levels $<5 \mathrm{ng} / \mathrm{ml}$ were considered as criteria of biochemical remission of disease (1). However, mortality rates remained high, and in 2000 the new and stringent consensus criteria for the treatment of acromegaly were presented $(2,10,25)$. According to this consensus, the random $\mathrm{GH}$ should be $<2.5 \mathrm{ng} / \mathrm{ml}, \mathrm{GH}$ had to be suppressed to $<1 \mathrm{ng} / \mathrm{ml}$ during OGTT, and IGF-I had to be within normal limits in order to consider acromegaly in complete remission $(10,21,25)$. With the recent development of highly sensitive and specific $\mathrm{GH}$ assays, the new and more strigent consensus criteria were presented in 2010, and this recent consensus described "remisssion" as random $\mathrm{GH}<1 \mathrm{ng} / \mathrm{ml}$ and IGF-I levels within an age- and sex-adjusted normal range, or nadir $\mathrm{GH}$ levels $<0.4 \mathrm{ng} / \mathrm{ml}$ with OGTT [18]. In the present study, we used more stringent 2010 consensus criteria to describe the endocrinological remission of acromegalic patients. There are many of endoscopic and microscopic transsphenoidal surgery series published using 2000 criteria for remission of acromegaly, and remission rates ranged from $42 \%$ to $70 \%$ (3, $10,12,20,27,29,31)$. In our series we had a hormonal remission rate of $74.6 \%$ according to the 2000 consensus criteria. The 2010 criteria are more stringent than 2000 criteria and it is more difficult to achieve a hormonal remission according to the new criteria. There are limited numbers of studies in literature according to the new criteria, and hormonal remission rates were reported between $46 \%-70 \%(12,15,16$, 29). In our series, hormonal remission was achieved in $66.1 \%$ of patients.

Tumor size predicted remission, and microadenomas had higher hormonal remission rates than macroadenomas in our series reported in numerous earlier publications $(15,17$, 29). In our current study, remission was achieved in $80 \%$ of microadenomas and in $64.7 \%$ of macroadenomas. Tumor size is not the most important predictive factor for remission. According to the previous large published series, tumor growth direction is very important. In this current study, we classified the patients according to suprasellar extension alone with Modified Hardy Classification. In the grade 0 and $A$ groups there were 44 patients and 29 have achieved remission (65.9\%). In the grade $B$ and $C$ groups there were 12 patients and 8 have achieved remission (66.6\%). This findings show that suprasellar extension alone does not affect the endoscopic transsphenoidal surgery success.

We also classified patients according to the suprasellar/ parasellar extension and sphenoid sinus invasion with the Hardy-Wilson classification. In this classification, stage shows supra- and parasellar extensions, and grade shows sphenoid sinus invasion. In stage 0 and group $A$, there were 35 patients and 28 have achieved remission (80\%). In stage $B, C$ and $D$, there were 11 patients and 8 have achieved remission (72.7\%). Stage $\mathrm{E}$ group (i.e. cavernous sinus invasion) had 10 patients and only 1 patient has achieved remission (10\%). In grade 1 and 2 groups, there were 31 patients and 28 have achieved remission (90.3\%). In group 3, 9 of 19 patients have achieved remission (47.3\%). In group 4, none of 6 patients have achieved remission ( $0 \%)$. These findings show that suprasellar extension does not affect the success of endoscopic transsphenoidal surgery, but invasive adenomas with cavernous and sphenoid sinus invasions affect the success rates. Although the surgical access to sphenoid sinus invasion is relatively easy, it affects the surgical success negatively. We believe that this is related to high degree of invasiveness of adenomas.

The other classification is Knosp classification, which is based upon the cavernous sinus invasion. In grade 0 and 1 groups, there were 22 patients and 20 have achieved remission (90.9\%). In grade 2 and 3 groups, there were 23 patients and 16 of them have achieved remission (69.5\%). In grade 4 group, only 1 of 11 patients has achieved remission (9\%). These findings show that Knosp grade is important for hormonal remission as described in previous studies $(12,16,17,29)$. There are profoundly successful results in utilizing endoscopic technique due to better illumination, direct entrance into the sella, and use of an angled endoscope, especially in Knosp grade 2 and 3 adenomas. The endoscopic technique is clearly superior to all other techniques in the treatment of adenomas with cavernous sinus invasion. Nevertheless, Knosp grade 4 adenomas could be treated by advanced endoscopic techniques, because of their certainly invasion (4).

For patients in whom biochemical remission is not achieved after the initial operation, physicians have few options such as medical management, radiosurgery and likelihood of repeat surgical intervention attempts. Repeat endoscopic transsphenoidal surgery is an effective and safe option for uncontrolled acromegalic patients, and has similar remission rates compared to medical therapy and radiosurgery (36). In our series, 16 patients underwent repeat operation for acromegaly by EETS after biochemical remission was not achieved following the first operation and medical therapy. Ten patients were operated via microscopic or endoscopic transsphenoidal approach and 4 patients were operated via transcranial approach by other authors. Only 2 patients were operated in our department via pure EETS by a senior author. All of these 16 patients were reoperated via pure EETS, and hormonal remission was achieved in 7 of them (43.7\%), and medical therapy was stopped. After reoperation, only 1 patient had different hormonal deficits, and no morbidity and mortality was observed. Reoperation for acromegaly is a safe, effective and cost-effective treatment option. In our opinion, reoperation via endoscopic transsphenoidal approach is the first-line treatment option for recurrent acromegaly if possible.

According to our present study, age, sex and preoperative $\mathrm{GH} / \mathrm{IGF}-1$ levels do not affect the remission rates. 


\section{CONCLUSION}

EETS is currently the first-line treatment option for GHsecreting pituitary adenomas with higher remission rates. The aim of this study was to discuss the remission rates of this important disease according to the new 2010 consensus criteria and to determine the predictive factors. In our opinion, excessive cavernous sinus invasion (Knosp grade 3-4), sphenoid sinus invasion (Hardy-Wilson stage E), failure of first surgery and surgeon experience are the most important factors that affect the surgery success. Consequently, surgery performed by an experienced surgeon using the most effective method is very important to achieve optimal results in the treatment of acromegaly, which has a negative impact on human life.

\section{REFERENCES}

1. Abosch A, Tyrrell JB, Lamborn KR, Hannegan LT, Applebury $\mathrm{CB}$, Wilson $\mathrm{CB}$ : Transsphenoidal microsurgery for growth hormone-secreting pituitary adenomas: Initial outcome and long-term results. J Clin Endocrinol Metab 83:3411-3418, 1998

2. Beauregard C, Truong U, Hardy J, Serri O: Long-term outcome and mortality after transsphenoidal adenomectomy for acromegaly. Clin Endocrinol (Oxf) 58: 86-91, 2003

3. Campbell PG, Kenning E, Andrews DW, Yadla S, Rosen M, Evans $\mathrm{JJ}$ : Outcomes after a purely endoscopic transsphenoidal resection of growth hormone-secreting pituitary adenomas. Neurosurg Focus 29(4):E5, 2010

4. Ceylan S, Koc K, Anik I: Endoscopic endonasal transsphenoidal approach for pituitary adenomas invading the cavernous sinus. J Neurosurg 112: 99-107, 2010

5. Chanson P, Salenave S, Kamenicky P, Cazabat L, Young J: Pituitary tumours: Acromegaly. Best Pract Res Clin Endocrinol Metab 23: 555-574, 2009

6. Cohen-Gadol AA, Liu JK, Laws ER Jr: Cushing's first case of transsphenoidal surgery: The launch of the pituitary surgery era. J Neurosurg 103: 570-574, 2005

7. De P, Rees DA, Davies N, John R, Neal J, Mills RG, Vafidis J, Davies JS, Scanlon MF: Transsphenoidal surgery for acromegaly in wales: Results based on stringent criteria of remission. Journal of Clinical Endocrinology and Metabolism 88: 3567-3572, 2003

8. Dekkers OM, Biermasz NR, Pereira AM, Romijn JA, Vandenbroucke JP: Mortality in acromegaly: A metaanalysis. J Clin Endocrinol Metab 93: 61-67, 2008

9. Draf W: Endonasal micro-endoscopic frontal sinus surgery: Fulda concept. Oper Tech Oto Head Neck Surg 2:234- 240, 1991

10. Giustina A, Barkan A, Casanueva FF, Cavagnini F, Frohman L, Ho K, Veldhuis J, Wass J, Von Werder K, Melmed S: Criteria for cure of acromegaly: A consensus statement. J Clin Endocrinol Metab 85: 526-529, 2000

11. Giustina A, Chanson P, Bronstein MD, Klibanski A, Lamberts $S$, Casanueva FF, Trainer P, Ghigo E, Ho K, Melmed S: A consensus on criteria for cure of acromegaly. J Clin Endocrinol Metab 95: 3141-3148, 2010
12. Gondim J.A, Almeida J.P, Albuquerque L.A.F, Gomes E, Schops $M$, Ferraz $T$ : Pure endoscopic transsphenoidal surgery for treatment of acromegaly: Results of 67 cases treated in a pituitary center. Neurosurg Focus 29(4): 1-6, 2010

13. Gondim JA, Ferraz T, Mota I, Studart D, Almeida JP, Gomes E, Schops M: Outcome of surgical intrasellar growth hormone tumor performed by a pituitary specialist surgeon in a developing country. Surg Neurol 72: 15-19, 2009

14. Gondim JA, Schops $M$, de Almeida JP, de Albuquerque LA, Gomes E, Ferraz T, Barroso FA: Endoscopic endonasal transsphenoidal surgery: Surgical results of 228 pituitary adenomas treated in a pituitary center. Pituitary 13: 68-77, 2010

15. Hazer DB, Isık $S$, Berker D, Güler S, Gürlek A, Yücel T, Berker $M$ : Treatment of acromegaly by endoscopic transsphenoidal surgery: Surgical experience in 214 cases and cure rates according to current consensus criteria. J Neurosurg 119(6):1467-1477, 2013

16. Hofstetter CP, Mannaa RH, Mubita L, Anand VK, Kennedy JW, Dehdashti AR, Schwartz TH: Endoscopic endonasal transsphenoidal surgery for growth hormone-secreting pituitary adenomas. Neurosurg Focus 29:E6, 2010

17. Jane JA, Starke RM, Elzoghby MA, Reames DL, Payne SC, Thorner MO, Marshall JC, Laws ER, Vance ML: Endoscopic Transsphenoidal surgery for acromegaly: Remission using modern criteria, complications, and predictors of outcome. J Clin Endocrinol Metab 96(9):2732-2740, 2011

18. Kaltsas GA, Isidori AM, Florakis D, Trainer PJ, Camacho-Hubner C, Afshar F, Sabin I, Jenkins JP, Chew SL, Monson JP, Besser GM, Grossman AB: Predictors of the outcome of surgical treatment in acromegaly and the value of the mean growth hormone day curve in assessing postoperative disease activity. J Clin Endocrinol Metab 86: 1645-1652, 2001

19. Knosp E, Steiner E, Kitz K, Matula C: Pituitary adenomas with invasion of the cavernous sinus space: A magnetic resonance imaging classification compared with surgical findings. Neurosurgery 33: 610-617, 1993

20. Kreutzer J, Vance ML, Lopes MB, Laws ER: Surgical management of $\mathrm{GH}$-secreting pituitary adenomas: An outcome study using modern remission criteria. J Clin Endocrinol Metab 86(9): 4072-4077, 2001

21. Kristof RA, Grote A, Redel L, Neuloh G, Klingmüller D, Schramm $\mathrm{J}$ :The common consensus criteria have high predictive values for long-term postoperative acromegaly remission. Acta Neurochir (Wien) 153: 19-25, 2011

22. Krzentowska-Korek A, Gołkowski F, Bałdys-Waligórska A, Hubalewska-Dydejczyk A: Efficacy and complications of neurosurgical treatment of acromegaly. Pituitary 14: 157-162, 2011

23. Ludecke DK, Abe T: Transsphenoidalmicrosurgery for newly diagnosed acromegaly: A personal view after more than 1,000 operations. Neuroendocrinology 83: 230-239, 2006

24. Melmed S: Acromegaly pathogenesis and treatment. J Clin Invest 119:3189-3202, 2009 
25. Melmed S, Casanueva FF, Cavagnini F, Chanson P, Frohman L, Grossman A, Ho K, Kleinberg D, Lamberts S, Laws E, Lombardi G, Vance ML, Werder KV, Wass J, Giustina A; Acromegaly Treatment Consensus Workshop Participants: Guidelines for acromegaly management. J Clin Endocrinol Metab 87: 40544058, 2002

26. Melmed $S$, Colao A, Barkan A, Molitch $M$, Grossman AB, Kleinberg D, Clemmons D, Chanson P, Laws E, Schlechte J, Vance ML, Ho K, Giustina A: Guidelines for acromegaly management: An update. J Clin Endocrinol Metab 94: 1509-1517, 2009

27. Nomikos P, Buchfelder M, Fahlbusch R: The outcome of surgery in 668 patients with acromegaly using current criteria of biochemical 'cure'. Eur J Endocrinol 152:379-387, 2005

28. Ross DA, Wilson CB: Results of transsphenoidal microsurgery for growth hormone-secreting pituitary adenoma in a series of 214 patients. J Neurosurg 68: 854-867, 1988

29. Shin SS, Tormenti MJ, Paluzzi A, Rothfus WE, Chang YF, Zainah $\mathrm{H}$, Fernandez-Miranda JC, Snyderman $\mathrm{CH}$, Challinor SM, Gardner PA: Endoscopic endonasal approach for growth hormone secreting pituitary adenomas: Outcomes in 53 patients using 2010 consensus criteria for remission. Pituitary 16(4):435-444, 2013

30. Tabaee A, Anand VK, Barrón Y, Hiltzik DH, Brown SM, Kacker A, Mazumdar M, Schwartz TH: Endoscopic pituitary surgery: A systematic review and meta-analysis. J Neurosurg 111: 545-554, 2009
31. Trepp R, Stettler C, Zwahlen M, Seiler R, Diem P, Christ ER: Treatment outcomes and mortality of 94 patients with acromegaly. Acta Neurochir (Wien) 147(3):243-251, 2005

32. Tutuncu Y, Berker D, Isik S, Ozuguz U, Akbaba G, Kucukler FK, Aydin Y, Guler S: Comparison of octreotide LAR and lanreotide autogel as post-operative medical treatment in acromegaly. Pituitary 15: 398-404, 2012

33. Wagenmakers MA, Netea-Maier RT, van Lindert EJ, Pieters GF, Grotenhuis AJ, Hermus AR: Results of endoscopic transsphenoidal pituitary surgery in 40 patients with a growth hormone-secreting macroadenoma. Acta Neurochir (Wien) 153(7):1391-1399, 2011

34. Wang YY, Higham C, Kearney T, Davis JR, Trainer $P$, Gnanalingham KK: Acromegaly surgery in Manchester revisited the impact of reducing surgeon numbers and the 2010 consensus guidelines for disease remission. Clin Endocrinol 76(3): 399-406, 2012

35. Wilson CB: Neurosurgical management of large and invasive pituitary tumors. In: Tindall GT, Collins WF, (eds). Clinical Management of Pituitary Disorders. New York: New York Raven Press, 1979:335-342

36. Wilson TJ, McKean EL, Barkan AL, Chandler WF, Sullivan SE: Repeat endoscopic transsphenoidal surgery for acromegaly: Remission and complications. Pituitary 16: 459-464, 2013

37. Yano S, Kawano T, Kudo M, Makino K, Nakamura H, Kai $Y$, Morioka M, Kuratsu J: Endoscopic endonasal transsphenoidal approach through the bilateral nostrils for pituitary adenomas. Neurol Med Chir 49: 1-7, 2009 